\title{
MASK AND PERSONA: CREATING THE BARD FOR BARDCOM
}

\author{
PETER HOLland
}

\begin{abstract}
This article explores a number of perspectives on the creation of very different Shakespeares as personas by first examining the celebration of the 400 th anniversary of his death in Stratford-upon-Avon in April 2016 and Shake, Mr Shakespeare, a remarkable Roy Mack 1936 Warner Brothers short. From there it moves on to consider the brief appearance of Shakespeare in the time-travel comedy Blackadder: Back and Forth, in 'The Shakespeare Code' episode of Doctor Who and in the off-Broadway musical Something Rotten!, before examining the work of Ben Elton in his screenplay for All Is True and in the seemingly unlikely success of Upstart Crow, the BBC sitcom with Shakespeare as the lead character, which has so far completed three six-episode series and three Christmas specials. The article is concerned with the multiple masks of the sequence of personas that create these Shakespeares, from Shakespeare as perhaps the epitome of the celebrity author to Shakespeare as a sitcom Dad.
\end{abstract}

\section{KEY WORDS}

Shakespeare, Mask, Celebrity, Comedy, Sitcom, Afterlife

\section{WHERE ISS SHAKESPEARE?}

In Act 2 of Emlyn Williams' The Corn is Green (1938), a semi-autobiographical narrative of how education saved a bright Welsh boy from the mines and sent him to Oxford University, the end of a class in Miss Moffat's new school leaves behind on stage Old Tom, "an elderly, distinguishedlooking, grey-bearded peasant" (Williams 1995, p. 34), and Miss Ronberry, now one of Miss Moffat's teachers. She turns to him 'nervously':

Miss Ronberry. Is there anything you would like to know, Mr. Tom?

Old Tom. Where iss Shakespeare?

Miss Ronberry. Where? Shakespeare, Mr. Tom, was a very great writer.

Old Tom. Writer? Like the Beibl?

Miss Ronberry. Like the Bible.

Old Tom. (Looking at her doubtfully). Dear me, and me thinkin' the man was a place.

When he exits, "(muttering sadly) If I iss been born fifty years later, I iss been top of the class", Miss Ronberry, as she closes the front door after him, can only say “Oh dear...” (pp. 36-7). 
The awkward representation of Welsh-inflected English apart (as in "iss" and "Beibl"), the patronising response to what is perceived as ignorance of elementary cultural knowledge marks a historical distance. It seems reasonable now to ask "Where is Shakespeare?" and, by the same standards, improbable that even a "grey-bearded peasant" would not know his name. Williams may be remembering such a figure but Shakespeare's global pervasiveness (as well as his place in compulsory education in the United Kingdom) makes Old Tom a historicised curiosity, a sign of a vision of spaces where Shakespeare's name was as yet unknown -even not too far from Stratford-upon-Avon.

It was already the case, at the date at which Williams was writing The Corn is Green, that the celebrations of Shakespeare's birthday in Stratford-upon-Avon had taken on more or less their present form. The easy availability now of British Pathé newsreel shows that there is little to choose between the events of 1920,1930, and 1950 and that all three are, to all intents and purposes, the same as those in, say, 2019 (British Pathé 1920, 1930, and 1950). The consistency of the procession through the streets is a marker of the civic, national, and international communities intersecting on the iconic status of the individual ranked in 2002 as the fifth 'Greatest Briton' (see '100 Greatest Britons').

The exception to the template for celebrating this celebrity of celebrities was in $2016 .^{\mathrm{i}}$ On Saturday, 23 April 2016, Shakespeare's birthday was, as usual, celebrated with that procession of civic dignitaries, academics, and assorted worthies through Stratford-upon-Avon, past the Birthplace, ending at Holy Trinity Church, where Shakespeare is buried, to lay bunches of spring flowers at the altar, making the cradle-to-grave journey through the town that mimics life and the conventional patterns of biography. Two moments in the morning's sequence were different that year. Since it was also the 400th anniversary of Shakespeare's death, the procession included a jazz band playing a New Orleans funeral carnival number. But, before that, people handed out 10,000 Shakespeare masks to the big crowd lining the town's streets and, at a given signal at 11 a.m., all of us put on our masks and, everywhere our eyes turned, there was Shakespeare.

But this was a Shakespeare masked, literally as a persona, as a character represented by a theatricalised mask, so that he became the multiple dramatis personae of his own 'deathversary', as it was dubbed. Where was Shakespeare at that moment? Everywhere one looked, reborn - one might almost say 'resurrected', given the quasi-religious tone of the proceedings in, or rather on, every one of us. What kind of person lies behind the mask, what person is concealed by the persona will be my concern throughout, taking me through a wide array of images of Shakespeare in action, of Shakespeare as character and performer, eventually landing on a sitcom starring Shakespeare, a new genre of tv drama, which has been dubbed 'Bardcom'. Since the word persona was itself Latin for the mask, I am exploring something that stretches the $O E D$ 's definition of it as “An assumed character or role, esp. one adopted by an author in his or her writing" (persona, $n$., 1.a). But as these various Shakespeare selves are created not by the author but by an other who re-creates the author as a mask, so the persona becomes "The aspect of a person's character that is displayed to or perceived by others" (2.a), but only as an aspect that hides as much as it reveals or, rather, reveals itself purely as construction, making the Shakespeare we would wish to see. 


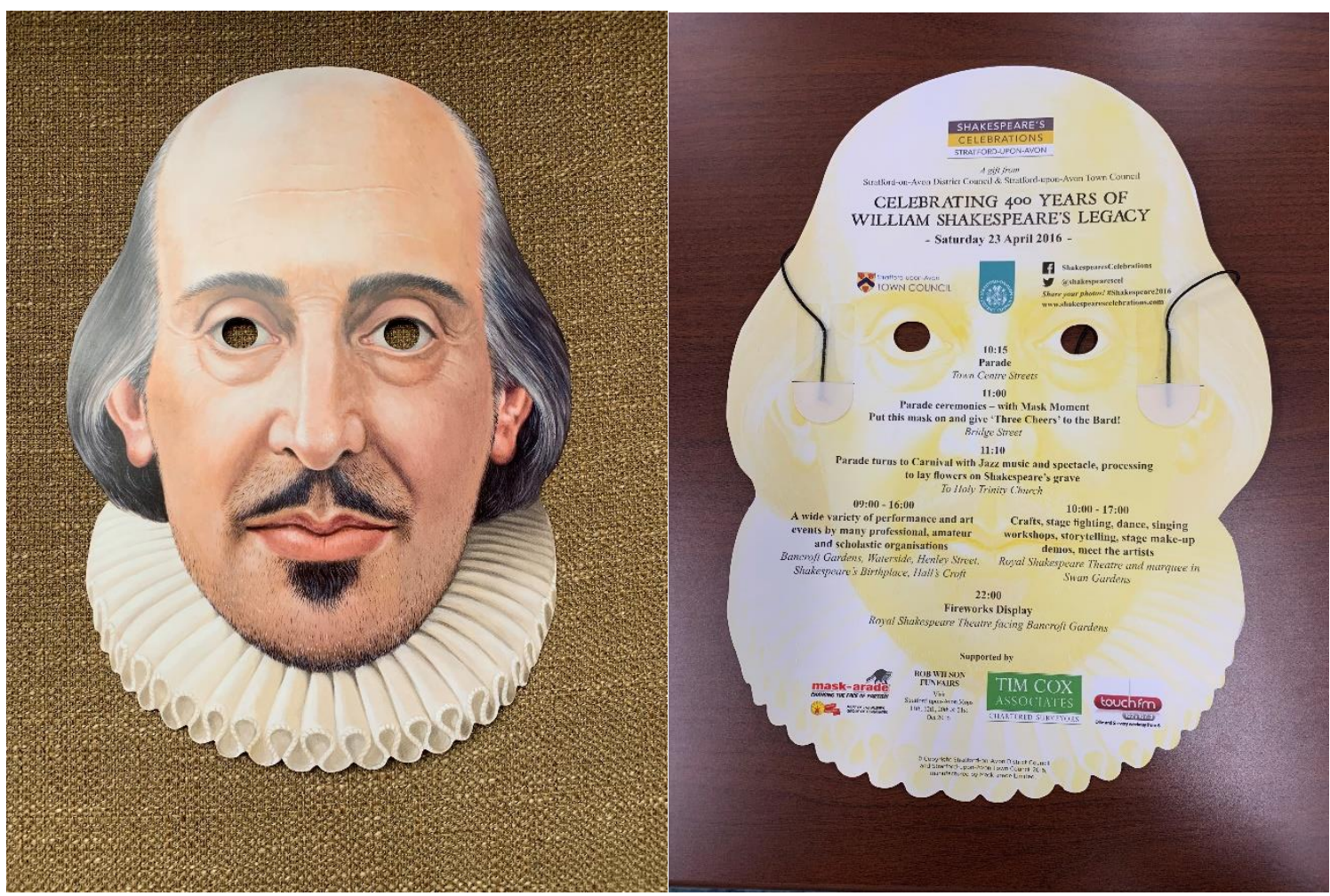

Fig. 1 \& 2: "A gift from Stratford-on-Avon District Council and Stratford-upon-Avon Town Council" for the "Mask Moment[.] Put this mask on and give 'Three Cheers' to the Bard!" (front and back), 2016 Celebration of "William Shakespeare's Legacy". Photo: Chloe Leach.

\section{SHAKING UP SHAKESPEARE}

Of the hundreds of works (poems, novels, and plays) in which Shakespeare figures as a character, he has appeared remarkably rarely as the butt of a comedy or indeed as a comic character, until recently. Even in a brief play of amorous misadventures like Alexandre Duval's Shakespeare Amoureux (1804), in which Shakespeare is in love with an actress confusingly called Clarence - Duval seems not to have known that there were no actresses on the early modern stage - Shakespeare is love-struck but not therefore funny. ${ }^{\text {ii }}$ Duval's play was first translated by Richard Penn Smith in the 1820s or 1830s as Shakespeare in Love, and there is a fairly short line from Clarence to Viola de Lesseps in John Madden's 1998 film. But the Shakespeare created for Madden by Marc Norman and Tom Stoppard's screenplay, nervously insecure as writer and lover, lacks the consciousness of celebrity that underpins subsequent comic Shakespeares.

One significant earlier version, a small step along the road with which I will be primarily concerned, is in Roy Mack's Shake, Mr Shakespeare (1936), one of Vitaphone's long series of 'Broadway Brevities', for which Mack was the most frequent director. Indeed, of the 26 short films made and released in the series in 1936, Mack directed 14 of them. This astonishing example of the genre, clearly made in anticipation of the imagined success of the Reinhardt and Dieterle 1935 film of $A$ Midsummer Night's Dream, made by Warner Brothers, of which Vitaphone was a part, is perfectly described by Deborah Cartmell as "extraordinarily eccentric" (Cartmell 2015, p. 43). As a junior executive, tasked by his boss to "read all Shakespeare's plays tonight and [to] let me know tomorrow morning what they are all about", iii falls asleep at his desk, a range of Shakespeare characters, summoned by Puck, emerge from the volumes of Shakespeare arranged in front of him, becoming part of his dreamscape. The characters are 
mostly predictable: Hamlet, Othello, Macbeth, Mark Antony, Romeo and Juliet. But there are also surprises like Henry VIII, seen dancing with all six of his wives, all of whom, incorrectly, he says he has had beheaded.

The film had opened with announcements of Shakespeare films supposedly 'coming' and so the characters expect to be Hollywood-bound, displacing the likes of Jimmy Durante, Wallace Beery, and Bill 'Bojangles' Robinson. Romeo and Juliet have quarrelled because, as Romeo puts it, "she's sore because I signed with Warners and she's going with MGM". Cue the first of a series of vaudeville acts, Juliet on her balcony singing a torch-song: "Romeo, where the heck are you? / Art thou giving the runaround to me?", ending with the lyrics "You ain't treating Shakespeare right. / Oh Romeo, you're doing history wrong." As Peter Quince changes the label on the Romeo and Juliet volume to Juliet and Romeo, he explains that "Her contract calls for feature billing", to which Hamlet replies "Ah, I see, she gets the billing and he gets the cooing" (Mack 1936). Subsequent acts include a completely bizarre novelty dance routine for Hamlet in the graveyard, offering convincing proof that Michael Jackson did not invent the moon-walk, accompanied by a chorus of tap-dancing female Hamlets (Cartmell calls them "Hamletettes", 2015, p. 43), each dancing on a tombstone. There is Mark Antony in the forum scene singing "Friends, Romans and countrymen, lend me your feet / To the tune we love, the rhythm of $42^{\text {nd }}$ Street" and, speaking of Caesar, encourages the spectators: "Let us celebrate / His Tragic fate / With a tempus fugit and a hi-de-ho."

Only at the end, as the characters are at "a Hollywood party", does Shakespeare make his entrance: "Cease, desist, forbear - and all other words meaning 'stop'. Is it for this I spilled such magic ink?"

Romeo. Oh, Bill, times have changed...

Hamlet. These days the screenplay's the thing.

Shakespeare. Fie to thee, fellow, fie. The characters that I wrote were solid, solid. Look at you now. Jellyfish all of you. You shake like jellyfish.

Falstaff. Oddsbodkins, Will, that's what you have to do today: you got to shake, $\mathrm{Mr}$ Shakespeare. (Mack 1936)

It is difficult to give the full flavour of this unusual concoction, even in a time when mash-ups are so familiar. But the overall effect of Shakespeare's arrival is to define as sharply as possible the extent to which he embodies a high cultural tradition against which the popular art-forms of Hollywood and vaudeville are being stacked. The characters seek their freedom, Ariel-like, from the bondage of the language and plots of Shakespeare's drama, wanting their own celebrity, like those of Hollywood stars, rather than the ones Shakespeare created and imposed. If his characters were indeed 'solid', then that is exactly what they no longer wish to be, finding a new mobility in their two-dimensionality for the studio system of film. From being characters they become actors and song-and-dance performers, in a historical mélange that they positively relish. It is no surprise here that the gravediggers from the Hamlet dance number are summoned by two Roman soldiers to the forum because they are needed after the murder of Julius Caesar.

Discarding their Shakespearean attributes, these figures are not merely content but positively excited to take up new genres, with Richard III looking to work in Westerns, where his call for a horse would make good sense. Their celebrity as Shakespeare characters equips them with a set of what we might now call transferable skills, malleable enough to take on new identities and, potentially, a new form of celebrity if they make it in Hollywood. Against their 
energy comes a Shakespeare more like Malvolio than any other of his creations, a party-pooper in this fun-loving 'New World'. Nothing about the performance of Shakespeare's drama seems half as enjoyable as the world of these vaudeville acts and the future movies they want to be in. Grumpy, prolix, concerned, a little smugly, to protect his own achievement, assured of the magnitude of what he did and its right to triumph over the decline of Western culture in the face of the new popular forms, this Shakespeare is not exactly endearing, not least when set against a high-kicking Hamlet. He is also not particularly comic.

This concept of Shakespeare as someone hugely famous and yet one whose art gives pleasure to no-one anymore, if indeed it ever did, is carried further in the encounter between Shakespeare (Colin Firth) and Lord Blackadder (Rowan Atkinson) in Blackadder: Back and Forth (1999), a time-travel adventure written by Richard Curtis, Ben Elton, and Rowan Atkinson and shown at the SkyScape cinema near the Millennium Dome, the site of the UK's millennial celebrations. At one moment, by chance Blackadder bumps into someone and sends his papers flying. Realising it is Shakespeare, Blackadder secures a signature:

Blackadder. Thank you. Oh, and just one more thing.

\section{Shakespeare. Yeah}

Blackadder. [punches him in the face] That is for every schoolboy and schoolgirl for the next four hundred years. Have you any idea how much suffering you're going to cause? Hours at school-desks trying to find one joke in A Midsummer Night's Dream, years wearing stupid tights in school plays and saying things like 'What ho, my Lord' and 'Oh look here comes Othello, talking total crap as usual'. 0 and [kicking him on the foot]...

Shakespeare. Ow.

Blackadder. That is for Ken Branagh's endless uncut four-hour version of Hamlet.

Shakespeare. Who's Ken Branagh?

Blackadder. I'll tell him you said that and I think he'll be very hurt. ('Blackadder vs. Shakespeare'] ${ }^{\text {iv }}$

That Firth's Shakespeare looks both in pain and confused seems only right: the blame game leaves Shakespeare responsible for everything done not by him but in his name. The sufferings of schoolchildren are the result, one might pompously say, not of the plays' failings but of the failure in the ways they have been taught to desk-bound pupils or in painfully traditional school plays. And, while Branagh's Hamlet (1996) is indeed interminable, that says more about Branagh's overweening aspirations than about Shakespeare's original, which certainly could not have run for four hours at the Globe. But punching and kicking Shakespeare is a neatly school-playground kind of response, childish as Blackadder so often is, but also as we do not like to admit to ourselves we would wish him to be. Here Shakespeare the individual becomes less a who than a what, the aggregation of the history of his cultural celebrity, a self that is becoming lost in the persona we have made from him and for him. Firth and, indeed, whoever wrote this sequence are creating a new Shakespeare mask, a Shakespeare who doesn't understand us and what we have made him to be. The self is no longer capable of recognising others' persona for him, the masks they have placed over him, even as he is represented in yet another mask through this new self. None of the masks is remotely supposed to be something one might once have termed a real Shakespeare, only a growing set of cultural and dramatic performances. 


\section{SHAKESPEARE AS CELEB}

When Blackadder gathers Shakespeare's papers, he finds himself holding 'The Tragedie of Macbeth':

Blackadder. Wait a minute. You're not...

Shakespeare. Will Shakespeare. Yes. Don't say it. I know. You hated Two Gentlemen of

Verona. This one's much better. ('Blackadder vs Shakespeare')

Later in the sequence of Shakespeares I am tracing, Shakespeare will be much less apologetic, indeed, positively irritated by the adulation he receives. In All is True, Branagh's 2018 film of Shakespeare in retirement, scripted by Ben Elton, Shakespeare is digging in his garden when "an earnest young student appears at the gate":

Henry. Mr. Shakespeare? I don't want to pester you.

Will. Good. Excellent news. Cheerio then.

Henry. It's just that I wanted to ask...

Will. The best way to get started as a writer is to start writing. Cheerio.

Henry. No really could I...

Will. I don't have a favourite play. I admire all my fellow dramatists equally. And yes I do think women should be allowed to perform the female roles as is the practice on the continent. Now please. If you'll excuse me.

Will returns to his digging. Defeated, Henry almost leaves but doesn't.

(Elton 2019, pp. 22-3)

The celebrity weary of being asked the same questions by legions of fans is a conventional trope of our fictions of fame. What links this passage most immediately to the moment in Blackadder: Back and Forth is a different question of authorship, not here who might have written the plays of Shakespeare but instead whether Ben Elton wrote both, for the distribution of authorship in the screenplay for this Blackadder is unclear. In between the two, Elton had started writing Upstart Crow for BBC2 (2016-18), the first ever bardcom, a sitcom improbably enough built around Shakespeare and successful enough to have so far run for three series, each of six episodes with three Christmas specials.

But the Shakespeare as weary celebrity in the film is only an extension of the Shakespeare as rock-star model that seems to me implicitly to underpin his appearance in "The Shakespeare Code', an episode of Doctor Who broadcast in 2007 (series 3, episode 2), and explicitly to define his identity in Something Rotten!, a 2015 musical, which won one of the ten Tony Awards for which it had been nominated, appropriately enough going to Christian Borle for Best Featured Actor in a Musical for his performance as Shakespeare. It was somehow inevitable that, sooner or later, Dr. Who would meet Shakespeare. Taking Martha, his new sidekick, on a time-travel journey to London in 1599, he shows her the exterior of the Globe Theatre:

Doctor....Oh, yes, the Globe Theatre! Brand new. Just opened. Through, strictly speaking, it's not a globe; it's a tetradecagon - 14 sides - containing the man himself. 
Martha. Whoa, you don't mean... is Shakespeare in there?v

It is the first night of Love's Labour's Lost and, when Martha gets the crowd shouting "Author, author" (Martha. "Do people shout that? Do they shout 'Author'?" Shakespeare. "Well... they do now."),

Shakespeare comes out and takes an exaggerated bow and blows kisses. Audience goes wild and cheers even louder...

Doctor. Genius. He's a genius - the genius. The most human human that's ever been. Now we're gonna hear him speak. Always, he chooses the best words. New, beautiful, brilliant words.

Shakespeare. Shut your big fat mouths!

Doctor. (disappointed) Oh, well.

Martha. You should never meet your heroes.

Shakespeare. You have excellent taste! I'll give you that. (Points to man in audience) Oh, that's a wig!

This smug, self-satisfied image of Shakespeare loving his fame and playing off the audience's adoration of him as celebrity, turns rather wearily, though still smugly, on the Doctor and Martha when they arrive to find him at the room in the tavern after the performance:

Doctor. Excuse me! I'm not interrupting, am I? Mr. Shakespeare, isn't it?

Shakespeare. Oh no, no, no, no. Who let you in? No autographs. No, you can't have yourself sketched with me. And please don't ask where I get my ideas from. Thanks for the interest. Now be a good boy and shove - (sees Martha standing behind the Doctor) Hey, nonny nonny. Sit right down here next to me. ('The Shakespeare Code' 2007)

More than a little boorish, loud-mouthed, and leeringly lecherous, this Shakespeare is closer to bored rock-star than dramatist. Only as the episode develops does his sharp intelligence begin to become apparent, a nicely shifting characterisation that energises the journey of the narrative, ending with him more like our ideal (sensitive, thoughtful, perceptive) than anything in his first scenes might suggest. But the tedium of celebrity, of always being asked the same questions, of everyone wanting an early modern selfie with him, is as apparent here in a midcareer Shakespeare as in the world-weary, depressed, retired Shakespeare of All is True.

In Something Rotten!, Shakespeare's big number in Act 1, 'Will Power', is set up as a performance, a solo show by a star, someone who is anything but bored by his fame, anything but unwilling to enjoy his fans' homage. As the Announcer's intro puts it,

Ladies and Gentlemen, all the way from Stratford Upon Avon, the King of Couplets, the Sultan of Sonnets, the man who put the 'I Am' in iambic pentameter, please put your hands together for the one, the only - William Shakespeare! (Kirkpatrick, Kirkpatrick \& O’Farrell 2015)

Working with the crowd as chorus, this Shakespeare's show is all about himself and he loves it: "I adore the adoration / Though others may appal [sic] it / It's quite the new sensation / What shall we call it?!", to which the chorus shouts back "Will power!", a phrase Shakespeare picks up on, "I am the Will of the people now". By the end, his self-adoration redefines him not only as the perfect piece of marketing - "I am the Will / I am the name you want to see up on that bill" - but also as divinely appointed: "The Chosen One that God in heaven smiled upon". Wondrously 
hyperbolic, this star is, of course, loathed by lesser mortals like Nick Bottom, would-be dramatist, whose opening number is "God, I hate Shakespeare" (Kirkpatrick, Kirkpatrick \& O’Farrell 2015).

These versions of Shakespeare converge as a trope of celebrity but they have, of course, no basis in any historical reality. What gives the anti-Stratfordians their own version of proof that Shakespeare did not write Shakespeare is precisely the absence of the kind of contemporary adulation that they are sure this corpus of drama would immediately have generated. But literary celebrity was hard enough to attain in a culture dominated by print. Dramatic celebrity was effectively unknown. Ben Jonson's aspirations, apparent on the titlepage of the collection of his plays as Works in 1616, was a wish for the status of a classic and he was mocked for it. Shakespeare may have left small bequests to his fellow-actors John Heminges and Henry Condell precisely because he had begun discussing with them the creation of the volume we know as the First Folio, Mr William Shakespeare's Comedies, Histories and Tragedies (1623), but he died seven years before it was published. The title-page, with its unprecedentedly massive image of author in the centre of it, screams to us of a celebrity identity, the fascination with the portrait as celebrity brand image offset by Ben Jonson' poem 'To the Reader', which is placed opposite and encourages us to "looke / Not on his Picture, but his Booke" (Jonson 1623). And the image itself could be seen as a kind of mask, as if Shakespeare himself is wearing a Shakespeare mask.

\section{SHAKESPEARE AND BARDCOM}

Writing on celebrity cultures usually manages simply to ignore Shakespeare, with his name hardly ever even appearing in the index.vi A Shakespeare who is not famous, not treated as a celebrity, not a cultural icon in his own time is simply not very interesting to current cultural expectations, with rare exceptions like the young up-and-coming playwright of Shakespeare in Love. There is also the exception, though I shall do no more than mention it, of the failed lutenist turned successful playwright Bill Shakespeare in Bill (2015), a not very successful featurelength film made by the otherwise brilliant Horrible Histories team.

Unsurprisingly, the comic image of Shakespeare for our times depends on his likeness to our own cultural systems. In that likeness he is effectively unhistoricised and, instead, embedded in a deliberate world of inauthenticity. This Shakespeare is comic precisely through a kind of self-awareness that screams its own impossibility. That that makes him different, consequent on an awareness of historical shift, is simply irrelevant and, in the favoured word of students everywhere, no longer 'relatable'. Shakespeare himself argues for an awareness of history and context in his message to those awaiting A-Level exam results in 2018:

Obviously my stuff is boring - it was written four hundred years ago. I know Hamlet goes on a bit but we had less distractions. If I was writing it today, I'd probably knock it off in a short rap. Yes, my jokes aren't funny. But do you really think your hilarious memes will still raise a giggle in the $25^{\text {th }}$ century. They're not even funny now, if you ask me. And what sort of arsingmongle is setting these questions? Did you ever read such Bolingbrokes? "Is my work sexist?" Derr! I lived in an age where women were literally male property! Apply some context! Zounds, it maketh me weep. Oh and by the way, if you're doing the Sonnets, yes, I did fancy the Earl of Southampton. Happy now? If we were alive today we'd probably be married with three adopted kids. But the point is: I'm not. I'm dead. And it's about time the people setting the A-level syllabus worked that out. Now futtock off and let me rest in peace. ('Shakespeare's A-Level Results Day Message' 2018) 
This is David Mitchell speaking as the Shakespeare he had been playing in Upstart Crow, whose third series was about to air. It has all the characteristics of the language Ben Elton created for this version of Shakespeare: occasional early modern words like 'Zounds' and equally occasional -eth endings for verbs; the creation of new swear words which, used often enough in the series, have taken on their own life, like 'futtock' or 'Bolingbrokes'. By the time Elton published the scripts for the first two series in 2018 he included a two-page glossary of these coinings (Elton 2018, pp. 356-7), none of which are early modern but all of which sound as if they should have been. This playfulness with fake-historicised language extends in the scripts to fake Elizabethan stage directions, such as "Marlowe doth place his boots upon the table most arrogantly" (p. 188), "Kate be buried in a book" (p. 185) or "Bottom speaketh in the manner of an aside, which by strict convention none can overhear" (p. 254).

But there is also in this the way Elton usually represents Shakespeare as angry or perhaps displaying merely an annoyed exasperation at the stupidity of the world, especially what the world expects of Shakespeare. As Mitchell explained in a radio interview:

It's taking William Shakespeare who previously we've seen dramatized as a romantic figure in Shakespeare in Love or has also been represented as a genius. But we see him as a classic sitcom dad, as someone struggling to make good in a world that's rejecting him, and struggling to keep his family together and struggling with an absolute nightmare commute. ('David Mitchell Chats to Craig Charles about Upstart Crow On Radio 2' 2018)

But Mitchell also identifies in Shakespeare a more substantial aspiration: "The whole show is about his struggle for what he feels he deserves which is eternal fame" ('David Mitchell Talks "Upstart Crow" Series 3 \& Learns About "Catfishing"' 2018). Part of this Shakespeare's route to such fame is through claiming as his own many phrases which, as Kate, Shakespeare's landlady's daughter and would-be actress, repeatedly and carefully points out, he has no claim on at all. It reaches its apogee in the following exchange in series 3 , episode 2 :

Marlowe. ....You know how it is: 'live by the sword, die by the sword'.

Shakespeare. Well, obviously I know, Kit: 'twas I that coined the phrase in my Richard, I think, or possibly a random Henry - lot of swords in those - but definitely one of mine.

Kate. Why then, Mr Shakespeare, call the watch, appeal to the Privy Council, cry foul and naughty tricks, for I fear you have been plagiarized.

Shakespeare. Plagiarized? By whom? Who's stealing my biggies? Name this thieving barnstaple.

Kate. The apostle Matthew.

Shakespeare. The swine - and him a man of God!

Kate. Mr. Shakespeare, 'He who lives by the sword shall die by the sword' is in the Bible.

Shakespeare. Really? You're sure?

Kate. Yes. Matthew, chapter 26 verse 52, although interestingly, he didn't come up with it either. A form of the phrase first appears in the ancient Greek play Agamemnon by the immortal dramatist Aeschylus.

Shakespeare. Well, if the apostle Matthew can pinch it, then so can I. Yes, Kit, definitely one of mine. (Blackadder, Series 3, Episode 2) 
It is the 'aside', straight to camera, that follows that points to his 'cunning plan' (as Baldrick, Elton's creation in Blackadder, frequently announces):

And so do I continue my private task of sowing confusion about what I actually wrote and what people merely think I did, till the day dawns when people, in their ignorance and vanity, will attribute any archaic-sounding truism to me in the certitude that it might easily have been me and, if it wasn't, nobody will know the diff. Thus will I eventually get credit for inventing the entire English language. So shove that up your Canterbury Tales, Geoffrey Chaucer (Series 3, Episode 2).vii

This endearing species of villainy, harmless in its vanity, even as it accuses us - or at least some of us - of the same sin, is a Shakespeare who already knows who or what he will become, a persona conscious of his own afterlife and already inhabiting it in a world that exists then and now simultaneously.

The multiple histories of Upstart Crow's presentation of celebrity persona are often attributed to a different interconnection of celebrities: on the one hand Ben Elton as successful comic sitcom author with Blackadder under his belt and, on the other, Sir Geoffrey Elton, Ben's uncle and the most brilliant Tudor historian of his generation. While I am far from sure that the nephew was in fact learning from the uncle, Upstart Crow becomes, in this tracing of family lineage, a little academic where its brilliance depends on its being willing to play as fast and loose with history as Shakespeare did and to be recognized for doing so.

Upstart Crow uses some historical detail and enjoys obfuscating other references. At no point, for instance, does the series explicate its title. Yet the title underpins some of the framework that runs through the series, for, as with all sitcoms, there is a template that becomes, over time, increasingly constricting, as the audience expects the repetitious forms, with mild variations, that each episode will largely offer, like some belated version of a Proppian morphology of folk-tales. In series 1, episode 4, Robert Greene, the villain of the London narrative, a magnificently over-the-top performance by Mark Heap, is given a soliloquy or, as the published script describes it, "The odious Greene doth sit before his desk": "Hmm, this upstart crow is ever more advanced in the world, beautifying himself in the feathers of a gentleman", to which Elton attaches a footnote that "Here Greene quotes a passage from his own description of Shakespeare in his Groatsworth of Wit, a book that would have been completely forgotten had it not contained a short passage slagging off Shakespeare" (Elton 2018, p. 90).

Greene's Groatsworth of Wit Bought with a Million of Repentance was published in 1592 and is the earliest extant reference to Shakespeare as a playwright. It purports to have been written "before his death and published at his dyeing request", as the title-page puts it. Directed to three other playwrights, probably Thomas Nashe, George Peele, and Christopher Marlowe, the pamphlet at one point attacks an unnamed upstart:

an vp=start Crow, beautified with our feathers, that with his Tygers hart wrapt in a Players hyde, supposes he is as well able to bombast out a blanke verse as the best of you: and beeing an absolute Iohannes fac totum is in his owne conceit the onely Shake-scene in a countrey. (Greene's Groatsworth of Wit 1592, sig. F1v)viii

Greene is complaining about this upstart who takes over the blank verse style of universityeducated dramatists. The tiger's heart is a reference to a line in Shakespeare's Henry VI Part 3 where the Duke of York describes Queen Margaret: "0, tiger's heart wrapped in a woman's hide" (1.4.138). Add that to the pun on Shakespeare's name in "Shake-scene" and it is clear that Greene is attacking Shakespeare - except that the pamphlet is not by Greene but, almost certainly, by the playwright and printer Henry Chettle (Jowett 1993). Greene's celebrity, more 
substantial at the moment of his death than either before or since, makes him a useful stalkinghorse for Chettle to use and to improve the sales of the pamphlet Chettle printed.

False attributions were an effective marketing ploy. In 1605 a play called The London Prodigal was published announcing itself as "by William Shakespeare", as Thomas Middleton's $A$ Yorkshire Tragedy was supposedly by "W. Shakespeare" in 1608, as was Sir John Oldcastle Part 1 in 1619. Various other plays were printed as "by W.S.", perhaps hinting at a Shakespeare connection. As Upstart Crow's Shakespeare claims phrases that were not his, so publishers used Shakespeare's name to sell others' plays.

At the heart of most episodes in the series is a combination of the sitcom dad - with his stroppy daughter, irritating foul-mouthed father, and struggles with the early modern equivalent of strikes and everything else that ensures his coach journey to Stratford is always

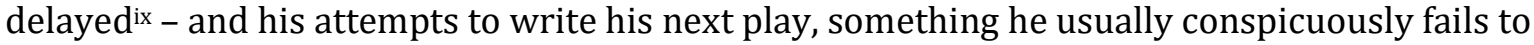
see emerging, even as we easily anticipate its arrival. Shakespeare is comically imperceptive about what materials in the events of the episode might form the stuff from which a play might be created. At the end of each episode, in a rather moving expression of domestic companionship, Shakespeare and his wife sit side by side by the fire, both smoking pipes, and chatting about what has been happening. After a story-line involving a Stratford farmer called Duncan MacBuff in which at, one point, Shakespeare has a vision of a milk jug ("Is this a milk jug which I see before me?...The handle toward my hand? Come, let me clutch thee”, [Elton 2018, p. 126]), Anne suggests to Will: "You know, husband, all these doings'd make a really good play":

Will. Yes, you're right. Of course! A light and breezy comedy about a laughable misunderstanding over some milk.

Anne. Well, actually, I was thinking more of the weird sisters, the ghost at the feast, the conscience-stricken wife endlessly washing her hands in the night. You know, a proper blood-and-guts thriller.

Will. No, no, I think comedy's the way to go. 'Two Milky Jugs' by William Shakespeare. (Elton 2018, p. 148) ${ }^{x}$

Anne's perceptiveness, her sense of future possibilities, as when she suggests the plot of Othello with a black actor in the lead (Shakespeare. "...a black actor in a leading role? I think that's a few centuries off", p. 209), makes Shakespeare, whose plays are derided throughout the series as painfully slow and incomprehensible, the comic butt of the narrative. Shakespeare's style is mocked for its distortions of syntax:

Will. ... 'must not a queen this murder do.'

Anne. Shouldn't that be, 'A queen must not do this murder'?

Will. Well, yes, it should, but I always think a sentence sounds better if you mix up the words a bit. It's one of my best tricks. (Elton 2018, p. 35)

And his predilection for inordinately over-elaborated circumlocutions results in equally overelaborate explanations: "I've sent word to the theatre that the two tunnels which lie beneath the bridge be blocked...Two tunnels? Beneath a bridge? Anyone? [All do stare at Will most blankly.] Nose, my loves! Nose! I've told Burbage that my nose be snotted" (Elton 2018, p. 6).

This Shakespeare is comic because, well, he is Shakespeare, the icon of high culture whose work, it is popularly assumed, nobody understands and nobody enjoys. Inept, hungry for fame, big-headed, worried about his increasing baldness, pompous, irritating and likeable in 
equal measure, this Shakespeare is the little man who wishes he were a celebrity. And his yearning is set against the other forms of modern celebrity that the scripts touch on, from Big Brother to the rock-star - here Thomas Morley with whom Susannah, Shakespeare's daughter, is besotted: "Thomas Morley is the best madrigal writer of the Renaissance. He is God. I would die for him. I'm a Thomatic" (p. 278), though, when Shakespeare brings her "an undershirt signed by Tommy Morley", he finds he is too late: “Don't like him any more. He sold out...He did a musical" (Elton 2018, p. 299).

I have been suggesting ways in which a range of recent representations of Shakespeare converge, often knowingly and often through the interconnections of individuals working on these projects. But there are also longer threads of similarities of which, I suspect, no-one engaged in these recent works is aware. Take, for instance, Elton's presentation of his scripts for Upstart Crow series 1 and 2 - or "The Crow Folios" as he dubs them (Elton 2018, p. vii) - with their inclusion of a version of a scholarly apparatus, "fulsomely annotated by the author", as the cover announces, not exactly a common feature of the publication of scripts for a TV sitcom. In 1810 John Poole published his Hamlet Travestie, complete with what the second edition of 1811 called "Burlesque Annotations after the manner of Dr. Johnson and Geo. Steevens, Esq. and the various commentators". As one of the title-page epigraphs puts it, borrowed from Edward Young's Love of Fame: The Universal Passion (1741), "Commentators each dark passage shun, / And hold their farthing candle to the sun". For anyone who reads the commentary notes in Shakespeare editions and even more for anyone who writes them, Poole's notes are alarmingly accurate and very funny. Here, for instance, is Poole ventriloquising Dr. Johnson, ostensibly in answer to Pope's suggestion that the phrase in the play "rope of onions" should be emended to "robe of onions":

Rope is, undoubtedly, the true reading. A rope of onions is a certain number of onions, which, for the convenience of portability, are, by the market-women, suspended from a rope: not, as the Oxford editor ingeniously but improperly supposes, in a bunch at the end, but by a perpendicular arrangement. For the hints afforded me in the formation of this note, ...I am indebted to a lady celebrated at once for her literary acquirements and her culinary accomplishments. (Poole 1811, p. 99)

Poole mocks the literati of his time as Elton does those of ours. Shakespeare is a means to satirise the pretensions of those who create such annotation.

Capacious in its range of targets, Upstart Crow finds in Shakespeare the mask through which we look at ourselves even as we look at the place we have accorded that impenetrable self that Shakespeare constitutes. As the mask reveals behind itself only another mask, a mise en abyme of personas, so Shakespeare is formed as a locus for the invisibility of the individual. More than anyone else, it seems, Shakespeare offers us the chance to invoke the absence of self through creating a sequence of replaceable masks. Barely human, always obscured, Shakespeare is the endlessly metamorphing chameleon that Keats identified:

The poetical Character is not itself - it has no self - it is everything and nothing - It has no character - it enjoys light and shade; it lives in gusto, be it foul or fair, high or low, rich or poor, mean or elevated - It has as much delight in an as an Imogen. What shocks the virtuous philosopher delights the camelion Poet. (Keats 1958, 1, pp. 386-7)

In the absence of that self all that can ever be seen is the mask of the persona, the what that 'iss' Shakespeare. 


\section{END NOTES}

i On the history of celebrating Shakespeare, see Calvo \& Kahn 2017.

ii On this and other early explorations of Shakespeare as character, see Holland 2005.

iii My transcription of the 'Inter-office Communication' shown in the film. The film is available on the current DVD release of $A$ Midsummer Night's Dream as a special feature.

iv See 'Blackadder vs. Shakespeare' https://www.youtube.com/watch?v=NM-Y1ch4b5c, my transcription.

v Transcriptions from http://who-transcripts.atspace.com/, checked by me against the DVD, accessed 24 May 2019.

vi Shakespeare manages two index points in the 519 pages of Marshall and Redmond's 2016 Companion to Celebrity, one of which occurs when Fred Inglis points out that Elizabeth I was famous "but very few knew of the hardworking drudge and playwright, Will Shakespeare" (Inglis 2016, p. 31).

vii My transcription; the scripts from series 3 of Upstart Crow have not been published.

viii See the helpful description on the Folger Shakespeare Library's Shakespeare Documented website: https://shakespearedocumented.folger.edu/exhibition/document/greenes-groatsworth-witte-first-printed-allusion-shakespeare-playwright (retrieved 28 August 2019).

ix I take it also to be part of this persona that, like most sitcom dads, Shakespeare sometimes uses slang in supremely awkward ways, as in episode 4 of series 1 , when he has finished his sonnet cycle: "Finished! By Jupiter's hairy armpits, bloody finished!...The cycle be complete. Result! Oh, yeah! Who the bard? Me the bard! Iambic pentameter is my bitch!" (Elton 2018, p. 91). Compare the last line with the intro to Shakespeare in Something Rotten!.

x Elton adds a footnote here: "If Shakespeare did write this play it is lost in the mists of time. Which is a great shame" (2018, p. 148).

\section{WORKS CITED}

'100 Greatest Britons', Wikipedia, retrieved 25 August 2019, $<$ https://en.wikipedia.org/wiki/100 Greatest Britons.>

'Blackadder vs. Shakespeare', 1999, YouTube, retrieved 26 August 2019, $<$ https://www.youtube.com/watch?v=NM-Y1ch4b5c>

British Pathé, 1920, 'Shakespeare’s Birthday 1920', retrieved 25 August 2019, $<$ https://www.britishpathe.com/video/shakespeares-birthday-1>

-1930, 'Shakespeare's Birthday On Sleeve As Shakespears Birthday 1930' [sic], retrieved 25 August 2019, <https://www.britishpathe.com/video/shakespeares-birthday-on-sleeveas-shakespears-bir $\geq$

-1950, 'Shakespeare's Birthday - A Royal Occasion 1950', retrieved 25 August 2019, $<$ https://www.britishpathe.com/video/shakespeares-birthday-a-royal-occasion>

Calvo, C.\& Kahn, C., eds., 2017, Celebrating Shakespeare, Cambridge University Press, Cambridge. Cartmell, D. 2015, Adaptations in the Sound Era: 1927-37, Bloomsbury Academic, London.

'David Mitchell Chats to Craig Charles about Upstart Crow On Radio 2', 2018, A Dose of David Mitchell on YouTube, retrieved 26 August 2019 $<$ https://www.youtube.com/watch?v=JIR07E6nJzc > 
'David Mitchell Talks 'Upstart Crow' Series 3 \& Learns About "Catfishing"', 2018, A Dose of David Mitchell on YouTube, retrieved 27 August 2019

$<$ https://www.youtube.com/watch?v=Iwe3pcUf1WY>

Elton, B. 2018, Upstart Crow: The Scripts, Penguin, London.

-2019, All is True. Shooting Script, Sony Pictures Classics, retrieved 26 August 2019, $<$ http://sonyclassics.com/awards-information/201819/screenplays/allistrue screenplay.pdf>

Greene's Groatsworth of Wit Bought with a Million of Repentance, 1592, William Wright, London.

Holland, P. 2005, 'Dramatizing the Dramatist', Shakespeare Survey, vol. 58, pp. 137-47.

Inglis, F. 2016, 'The Moral Concept of Celebrity', in P. D. Marshall, S. Redmond (eds.), $A$ Companion to Celebrity, John Wiley and Sons, Chichester, pp. 21-38.

Jonson, B. 1623, 'To the Reader', The Cambridge Edition of the Works of Ben Jonson Online, Cambridge University Press, retrieved 26 August 2019, <http://ezproxyprd.bodleian.ox.ac.uk:2204/cambridge/benjonson/k/works/shakesreader/facing/\#>

Jowett, J. 1993, 'Johannes Factotum: Henry Chettle and Greene's Groatsworth of Wit', The Papers of the Bibliographical Society of America, vol. 87, no. 4, pp. 453-86.

Keats, J. 1958, The Letters of John Keats, H E Rollins (ed.), 2 vols., Cambridge University Press, Cambridge.

Kirkpatrick, K., Kirkpatrick, W. \& O’Farrell, J. 2015, 'Liner Notes', Something Rotten!. Original Broadway Cast Recording, Ghostlight Records.

Mack, R. 1936 / 2007, Shake, Mr Shakespeare. On William Shakespeare, A Midsummer Night's Dream, dir. Reinhardt and Dieterle, DVD, Turner Entertainment.

Marshall, P. D. \& Redmond, S. (eds.), 2016. A Companion to Celebrity, John Wiley and Sons, Chichester.

Poole, J. 1811, Hamlet Travestie, $2^{\text {nd }}$ ed., J.M.Richardson, London.

Shakespeare, W. 1997, The True Tragedy of Richard Duke of York and the Good King Henry the Sixth (Henry VI Part Three), in S. Greenblatt et al. (eds.), The Norton Shakespeare, W. W. Norton, New York \& London.

'Shakespeare's A-Level Results Day Message', 2018, A Dose of David Mitchell on YouTube, retrieved 26 August 2019, <https://www.youtube.com/watch?v=eTVYNEFQs-0>

'The Shakespeare Code', 2007, Doctor Who series 3, episode 2, Dr Who Transcripts, retrieved 24 May 2019, <http://who-transcripts.atspace.com/>

Williams, E. 1995, The Corn is Green, Samuel French, London. 